\title{
Vagococcus penaei sp. nov., isolated from spoilage microbiota of cooked shrimp (Penaeus vannamei)
}

\author{
Emmanuel Jaffrès, ${ }^{1,2}$ Hervé Prévost, ${ }^{1}$ Albert Rossero, ${ }^{1}$ \\ Jean-Jacques Joffraud ${ }^{2}$ and Xavier Dousset ${ }^{1}$ \\ ${ }^{1}$ UMR INRA 1014 SECALIM ENITIAA, rue de la Géraudière, BP 82225, 44322 Nantes Cedex 3, \\ France \\ ${ }^{2}$ Ifremer, Laboratoire Science et Technologie de la Biomasse Marine, BP 21105, 44311 Nantes \\ Cedex 3, France
}

Correspondence

Xavier Dousset

dousset@enitiaa-nantes.fr

\begin{abstract}
A polyphasic taxonomic study, using phenotypic, phylogenetic and genotypic characterization, was performed on five Gram-stain-positive, catalase-negative, coccus-shaped Vagococcus-like bacteria isolated from the spoilage microbiota of cooked shrimp. Comparative 16S rRNA gene sequence analysis indicated that the isolates belonged to the genus Vagococcus. The five isolates shared 100\% 16S rRNA gene sequence similarity, and representative strain CD276 ${ }^{\top}$ formed a branch that was distinct from the type strains of the six recognized species of the genus Vagococcus (Vagococcus fluvialis CCUG $32704^{\top}$, V. salmoninarum NCFB $2777^{\top}$, V. lutrae CCUG $39187^{\top}$, V. fessus M2661/98/1 ${ }^{\top}$, V. carniphilus ATCC BAA-340 ${ }^{\top}$ and V. elongatus $\mathrm{PPC}^{\top}$ ). The taxonomic position of strain $\mathrm{CD}^{2} 26^{\top}$ was clarified using DNA-DNA hybridization, pulsed-field gel electrophoresis of whole-genome DNA, G+C content determination, cell-wall peptidoglycan typing, fatty acid analysis and biochemical characterization. On the basis of this evidence, a novel species, Vagococcus penaei sp. nov., is proposed. The type strain is CD276 $\left(=\right.$ LMG $24833^{\top}=$ CIP $109914^{\top}$ ).
\end{abstract}

The bacterial genus Vagococcus was proposed by Collins et al. (1989) in order to improve the taxonomy of Grampositive, catalase-negative, motile, coccus-shaped bacteria that are close to the lactococci in terms of reacting with Lancefield group $\mathrm{N}$ antisera but are phylogenetically distant. Phylogenetic studies have shown that the closest relatives of the genus Vagococcus are the genera Enterococcus and Carnobacterium (Wallbanks et al., 1990). To date, the genus Vagococcus consists of six species. The first described was Vagococcus fluvialis, which was isolated from chicken faeces and seawater (Hashimoto et al., 1974), various internal organs of domestic animals such as pigs, cattle, cats and horses (Pot et al., 1994), human clinical samples such as blood, peritoneal fluid and wounds (Teixeira et al., 1997) and, more recently, from a rootfilled tooth with periradicular lesions (Al-Ahmad et al., 2008). Vagococcus salmoninarum was recognized by Wallbanks et al. (1990) and has been isolated from diseased fish such as Atlantic salmon, rainbow and brown trout (Michel et al., 2007; Ruiz-Zarzuela et al., 2005; Schmidtke \& Carson, 1994; Wallbanks et al., 1990). Two further species were found subsequently in marine mammals and allocated to the genus: Vagococcus lutrae (Lawson et al.,

Abbreviation: PFGE, pulsed-field gel electrophoresis.

The GenBank/EMBL/DDBJ accession number for the 16S rRNA gene sequence of strain $\mathrm{CD}^{2} 76^{\top}$ is $\mathrm{FJ} 360897$.
1999), isolated from the common otter (Lutra lutra), and Vagococcus fessus (Hoyles et al., 2000), from a seal and a harbour porpoise. In the last few years, two more species have been isolated: Vagococcus carniphilus from ground beef (Shewmaker et al., 2004) and Vagococcus elongatus from a swine-manure storage pit (Lawson et al., 2007). Recently, we isolated five Vagococcus-like bacteria from the microbiota of spoiled cooked shrimp (Jaffrès et al., 2009). The present work describes the polyphasic taxonomic study of a representative strain, CD $276^{\mathrm{T}}$.

The five isolates, designated $\mathrm{CD} 276^{\mathrm{T}}$, CD279, CD285, CD310 and CD380, were collected from a batch of cooked, peeled, brined and drained shrimp (Penaeus vannamei harvested in the Pacific Ocean) that had been packaged in a modified atmosphere and were considered as spoiled by a trained panel experienced in the sensory evaluation of seafood. Details of the sensory and microbiological monitoring, strain collection and identification can be found in our previous study (Jaffrès et al., 2009).

The phylogenetic position of the five isolates was determined by complete $16 \mathrm{~S}$ rRNA gene sequence analysis. Genomic DNA extraction and purification were carried out using the DNeasy Blood and Tissue kit (Qiagen). Amplification, purification and sequencing of the $16 \mathrm{~S}$ rRNA gene were performed as described by Valcheva et al. (2006). Sequence analysis using the BioEdit sequence 
alignment software (Hall, 1999) revealed that the five isolates shared $100 \% 16 \mathrm{~S}$ rRNA gene sequence similarity. The 16S rRNA gene sequence of strain CD276 ${ }^{\mathrm{T}}$ and those of strains of the most closely related genera, Vagococcus and Enterococcus, from GenBank and the Ribosomal Database Project (http://rdp.cme.msu.edu; Cole et al., 2003) were aligned using CLUSTAL in MEGA version 4.0 and a neighbourjoining phylogenetic tree was created (Tamura et al., 2007) with Kimura's two-parameter model (Gascuel, 1997; Kimura, 1980) on 1425 gap-free sites (Fig. 1). Sequences from the genera Vagococcus and Enterococcus clustered into two distinct monophyletic groups, and the close association of strain $\mathrm{CD} 276^{\mathrm{T}}$ with members of the genus Vagococcus was confirmed by a bootstrap value of $99 \%$. After realigning the distance matrix with CLUSTAL $\mathrm{W}$, strain $\mathrm{CD} 276^{\mathrm{T}}$ formed a distinct branch with the four other isolates that shared a node with $V$. carniphilus ATCC BAA$640^{\mathrm{T}}$ and $V$. fluvialis CCUG $32704^{\mathrm{T}}$ with a bootstrap value of $99 \%$. Strain $\mathrm{CD}_{276^{\mathrm{T}}}$ shared high $16 \mathrm{~S}$ rRNA gene sequence similarities with $V$. carniphilus ATCC BAA- $640^{\mathrm{T}}$ $(97.5 \%)$ and $V$. fluvialis CCUG $32704^{\mathrm{T}}(97.3 \%)$ and lower sequence similarities were observed with the other type strains of the genus Vagococcus [V. lutrae CCUG $39187^{\mathrm{T}}$ (96.2\%), V. elongatus PPC9 $^{\mathrm{T}}$ (95.6\%), V. salmoninarum NCFB $2777^{\mathrm{T}}(95.1 \%)$ and $V$. fessus M2661/98/1 $\left.{ }^{\mathrm{T}}(94.2 \%)\right]$. These results indicated that the group of five isolates was phylogenetically distinct from the six Vagococcus species already recognized.

Strain $\mathrm{CD} 276^{\mathrm{T}}$ was characterized phenotypically using conventional morphological and biochemical tests. All phenotypic tests were performed at $30{ }^{\circ} \mathrm{C}$ except for growth tests at 10 and $45^{\circ} \mathrm{C}$. Cell morphology and motility were studied by phase-contrast microscopy. Motility was also examined in mannitol-nitrate mobility (MNM) medium (Bio-Rad), which was inoculated by stabbing the centre of the tube. Growth was studied in brain-heart infusion (BHI) broth with $0.1 \%$ glucose and bromcresol purple indicator at 10 and $45{ }^{\circ} \mathrm{C}$ or with $6.5 \% \mathrm{NaCl}$. Haemolysis was assessed on Columbia agar supplemented with $5 \%$ defibrinated horse blood (Bio-Rad) with 5-10\% $\mathrm{CO}_{2}$. Gas production from glucose was examined in MRS medium (Biokar Diagnostic) using Durham tubes sealed with melted petroleum jelly. Cells of strain $\mathrm{CD} 276^{\mathrm{T}}$ were Gram-stain-positive, catalase-negative, coccus-shaped bacteria $(0.5-1 \mu \mathrm{m})$ that occurred singly, in pairs or in short chains, elongated in the direction of the chain, and were determined to be non-motile by microscopic and MNM medium observations. Colonies were small $(0.5-1 \mathrm{~mm})$, smooth and white on BHI agar at $30^{\circ} \mathrm{C}$. Strain CD276 ${ }^{\mathrm{T}}$ was facultatively anaerobic and produced lactic acid but not gas from glucose.

Sugar fermentation patterns and enzyme activities were determined for the five isolates with the API Rapid ID32S and API ZYM systems (bioMérieux), respectively, according to the manufacturer's instructions. All tests were carried out at least in duplicate. The detailed biochemical characteristics of strain $\mathrm{CD} 276^{\mathrm{T}}$ are presented in the species description and in Table 1. Some of the results for sugar fermentation and enzyme activities were variable between the isolates: CD279, CD285 and CD380 had identical

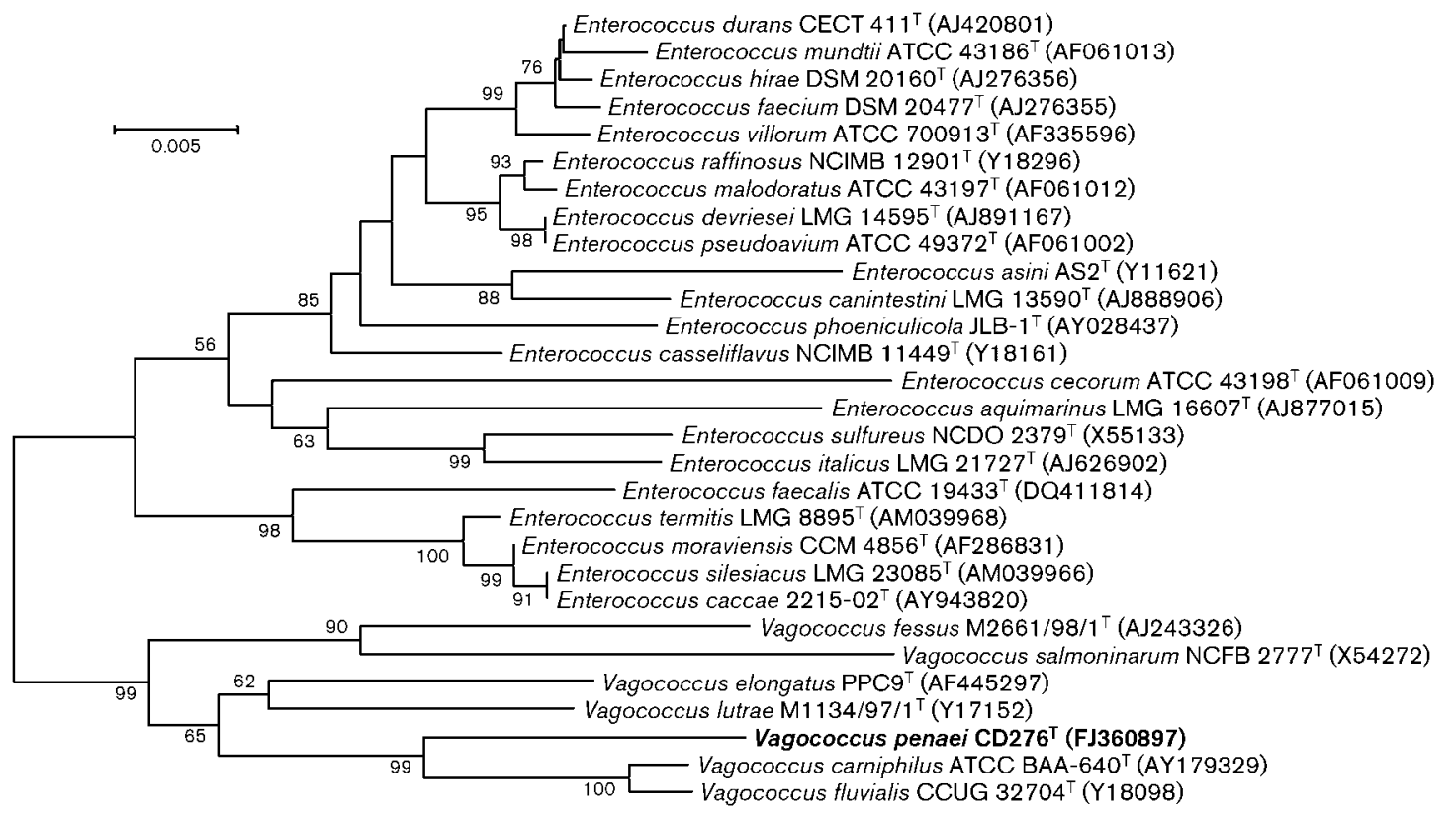

Fig. 1. Neighbour-joining phylogenetic tree based on 16S rRNA gene sequence analysis, showing the relationships of strain CD276 ${ }^{\top}$ with the type strains of Vagococcus species and strains of selected Enterococcus species. Bootstrap values ( $>50 \%$ ) based on 1000 replicates are shown at branch nodes. Bar, 0.005 substitutions per nucleotide position. 
profiles but differed from $\mathrm{CD} 276^{\mathrm{T}}$ in six reactions $(\alpha-$ cyclodextrin, $\alpha$-chymotrypsin, $\alpha$-glucosidase, arginine dihydrolase, glycyl-tryptophan arylamidase and leucine arylamidase) and from CD310 in eight reactions (raffinose, Dsorbitol, methyl $\beta$-D-glucopyranoside, $\alpha$-cyclodextrin, $\beta$ glucosidase, $\beta$-mannosidase, arginine dihydrolase and glycyl-tryptophan arylamidase). Strain $\mathrm{CD} 276^{\mathrm{T}}$ was the second most reactive compared with the type strains of described Vagococcus species, having 15 positive reactions and one weakly positive reaction. $V$. lutrae CCUG $39187^{\mathrm{T}}$ was the most reactive, having 18 positive reactions and five weakly positive reactions. Four reactions were positive for strain CD276 ${ }^{\mathrm{T}}$ exclusively and not for any other type strain: these were melezitose and raffinose acidification, arginine dihydrolase activity and acetoin production (VogesProskauer). Furthermore, strain $\mathrm{CD} 276^{\mathrm{T}}$ produced acid from several other carbohydrates, such as maltose, Dribose, sucrose, trehalose and $\alpha$-cyclodextrin, and displayed activity for acid phosphatase, glycyl-tryptophan arylamidase, naphthol-AS-BI-phosphohydrolase and pyroglutamic acid arylamidase and weak activity for $\beta$-glucosidase, esterase (C4) and esterase lipase (C8).

An analysis of the peptidoglycan structure of strain CD276 ${ }^{\mathrm{T}}$ was carried out as described by Schleifer (1985) and Schleifer \& Kandler (1972) with the modification that TLC on cellulose was applied instead of paper chromatography. Strain CD276 ${ }^{\mathrm{T}}$ possessed a cell-wall peptidoglycan of type A4 $\alpha$ L-Lys-D-Asp (type A11.31; http://www.dsmz. $\mathrm{de} /$ microorganisms/main.php?content_id=35).

For the quantitative analysis of cellular fatty acids, strain $\mathrm{CD} 276^{\mathrm{T}}$ was grown for $24 \mathrm{~h}$ on the medium described by Fischer \& Arneth-Seifert (1998). Cells were harvested and cellular fatty acids were saponified, methylated and extracted as described by the instructions of the Sherlock Microbial Identification System (MIDI, 1999). Fatty acids were analysed by GC (model 6890; Hewlett Packard) and identified using the Microbial Identification software (Sasser, 1990). The predominant cellular fatty acids of strain $\mathrm{CD}_{276^{\mathrm{T}}}$ were cis-9 octadecenoic acid $(18: 1 \omega 9 c$,

Table 1. Phenotypic characteristics of isolates of Vagococcus penaei sp. nov. and the type strains of closely related Vagococcus species

Reference strains: 1, V. fluvialis CCUG $32704^{\mathrm{T}} ; 2$, V. salmoninarum CCUG $33394^{\mathrm{T}} ; 3$, V. carniphilus CCUG 46823 ${ }^{\mathrm{T}}$; 4, V. lutrae CCUG $39187^{\mathrm{T}}$; 5 , V. fessus CCUG $41755^{\mathrm{T}} ; 6$, V. elongatus CCUG $51432^{\mathrm{T}}$. Data for reference strains were taken from the CCUG database (http://www.ccug.se). + , Positive; w, weakly positive; -, negative.

\begin{tabular}{|c|c|c|c|c|c|c|c|c|c|c|c|}
\hline \multirow[t]{2}{*}{ Characteristic } & \multicolumn{5}{|c|}{ Vagococcus penaei sp. nov. } & \multirow[t]{2}{*}{1} & \multirow[t]{2}{*}{2} & \multirow[t]{2}{*}{3} & \multirow[t]{2}{*}{4} & \multirow[t]{2}{*}{5} & \multirow[t]{2}{*}{6} \\
\hline & $\mathrm{CD}^{276^{\mathrm{T}}}$ & CD279 & CD285 & CD380 & CD310 & & & & & & \\
\hline Maltose & + & + & + & + & + & + & - & + & + & - & - \\
\hline Melezitose & + & + & + & + & + & - & - & - & - & - & - \\
\hline Raffinose & + & + & + & + & - & - & - & - & - & - & - \\
\hline Sucrose & + & + & + & + & + & + & - & - & + & - & - \\
\hline Trehalose & + & + & + & + & + & + & + & + & + & - & - \\
\hline Methyl $\beta$-D-glucopyranoside & - & - & - & - & + & - & - & + & + & - & - \\
\hline$\alpha$-Cyclodextrin & + & - & - & - & + & + & - & + & + & - & - \\
\hline \multicolumn{12}{|l|}{ Enzyme activities } \\
\hline$\beta$-Mannosidase & - & - & - & - & + & $\mathrm{w}$ & - & - & + & - & - \\
\hline Acid phosphatase & + & + & + & + & + & + & + & - & + & - & - \\
\hline Alkaline phosphatase & - & - & - & - & - & - & $\mathrm{w}$ & $\mathrm{w}$ & $\mathrm{w}$ & - & $\mathrm{w}$ \\
\hline Arginine dihydrolase & + & - & - & - & + & - & - & - & - & - & - \\
\hline Esterase (C4) & + & + & + & + & + & $\mathrm{w}$ & $\mathrm{w}$ & - & $\mathrm{w}$ & $\mathrm{w}$ & $\mathrm{W}$ \\
\hline Esterase lipase (C8) & + & + & + & + & + & + & $\mathrm{w}$ & - & + & $\mathrm{w}$ & $\mathrm{W}$ \\
\hline Glycyl-tryptophan arylamidase & + & - & - & - & + & + & + & + & + & $\mathrm{w}$ & + \\
\hline Leucine arylamidase & - & + & + & + & + & - & + & + & + & + & - \\
\hline Naphthol-AS-BI-phosphohydrolase & + & + & + & + & + & + & - & - & $\mathrm{w}$ & $\mathrm{w}$ & - \\
\hline Pyroglutamic acid arylamidase & + & + & + & + & + & $\mathrm{w}$ & + & + & + & + & - \\
\hline Acetoin production (Voges-Proskauer) & + & + & + & + & + & - & - & - & - & - & - \\
\hline
\end{tabular}


$30.43 \%)$ and hexadecanoic acid $(16: 0 ; 16.37 \%)$. The complete fatty acid composition of strain $\mathrm{CD} 276^{\mathrm{T}}$ is shown in Table 2.

The analysis of chromosomal DNA restriction patterns for the five isolates was carried out by pulsed-field gel electrophoresis (PFGE) as described by Teixeira et al. (1997). Genomic DNA was digested with SmaI in agarose plugs and electrophoresed on $1.3 \%$ agarose in TBE using the CHEF-DR III system (Bio-Rad). Band patterns were visualized and photographed under UV light. The PFGE profiles for the five isolates displayed two different banding patterns: one for isolates CD276 ${ }^{\mathrm{T}}$ and CD279 and another for isolates CD285, CD310 and CD380 (Fig. 2). The two patterns differed in eight bands. Thus, the two groups probably represent two distinct strains. The variation in PFGE profiles among the five isolates fulfils the recommendation of the International Committee for the Systematics of Prokaryotes for the basis of describing a species through the study of more than one strain (Stackebrandt et al., 2002).

For the determination of $\mathrm{G}+\mathrm{C}$ content, genomic DNA was prepared according to Gevers et al. (2001). The DNA G + C content was determined in triplicate by using HPLC (Mesbah et al., 1989). The DNA G +C content of strain $\mathrm{CD} 276^{\mathrm{T}}$ was $35.4 \mathrm{~mol} \%$. This value is within the range (33.6-44.5 mol\%) reported for the six recognized species of the genus Vagococcus.

DNA-DNA hybridization was carried out by the BCCM/ LMG Bacteria Collection (University of Gent, Belgium) with genomic DNA prepared according to a modification of the procedure described by Gevers et al. (2001). Hybridization was performed at $35{ }^{\circ} \mathrm{C}$ using the fluorometric method in duplicate, according to a modification of the method described by Ezaki et al. (1989). Table 3 shows

Table 2. Fatty acid content of strain CD276

\begin{tabular}{|c|c|c|}
\hline Fatty acid & Systematic name & $\begin{array}{c}\text { Proportion } \\
\text { (\%) }\end{array}$ \\
\hline $10: 0$ & Decanoic acid & 2.30 \\
\hline $12: 0$ & Dodecanoic acid & 1.79 \\
\hline $12: 03-\mathrm{OH}$ & 3-Hydroxydodecanoic acid & 0.64 \\
\hline $14: 0$ & Tetradecanoic acid & 9.80 \\
\hline $13: 02-\mathrm{OH}$ & 2-Hydroxytridecanoic acid & 0.51 \\
\hline $15: 1 \mathrm{~F}$ & 13-Methyltetradecenoic acid isomer F & 1.11 \\
\hline $16: 1 \omega 9 c$ & cis-9 Hexadecenoic acid & 8.45 \\
\hline $16: 0$ & Hexadecanoic acid & 16.37 \\
\hline iso- $17: 1 \omega 9 c$ & 15-Methyl cis-9 hexadecenoic acid & 1.06 \\
\hline iso- $17: 1 \omega 5 c$ & 15-Methyl cis-5 hexadecenoic acid & 1.27 \\
\hline $18: 1 \omega 9 c$ & cis-9 Octadecenoic acid & 30.43 \\
\hline $18: 1 \omega 7 c$ & cis-7 Octadecenoic acid & 4.20 \\
\hline $18: 0$ & Octadecanoic acid & 6.29 \\
\hline $19: 1$ & Nonadecenoic acid & 3.49 \\
\hline $20: 1 \omega 9 c$ & cis-9 Eicosenoic acid & 5.88 \\
\hline $20: 1 \omega 7 c$ & cis-7 Eicosenoic acid & 0.83 \\
\hline
\end{tabular}

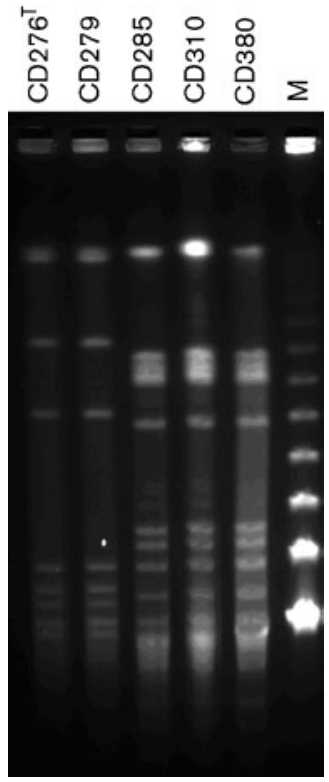

Fig. 2. Restriction patterns by PFGE of genomic DNA of isolates of Vagococcus penaei sp. nov. after Smal digestion. M, Markers.

the mean DNA-DNA relatedness obtained between strain $\mathrm{CD} 276^{\mathrm{T}}$ and the type strains of the two phylogenetically most closely related species, V. carniphilus CIP $108561^{\mathrm{T}}$ and $V$. fluvialis LMG $9464^{\mathrm{T}}$. The DNA-DNA hybridization experiments confirmed the phylogenetic grouping with the $16 \mathrm{~S}$ rRNA gene sequence, with strain $\mathrm{CD} 276^{\mathrm{T}}$ having DNA-DNA relatedness of 14 and $18 \%$ with $V$. carniphilus CIP $108561^{\mathrm{T}}$ and $V$. fluvialis LMG $9464^{\mathrm{T}}$, respectively. These values were below the threshold of $70 \%$ suggested for the delineation of species (Stackebrandt \& Goebel, 1994; Wayne et al., 1987) and indicated that strain CD276 ${ }^{\mathrm{T}}$ represents a novel genomic species.

\section{Description of Vagococcus penaei sp. nov.}

Vagococcus penaei [pe.na'e.i. N.L. gen. n. penaei of Penaeus, a zoological genus name, pertaining to the spoilage microbiota of cooked shrimp (Penaeus vannamei), from which the type strain was isolated].

Table 3. Mean DNA-DNA relatedness between strain $\mathrm{CD}^{276}{ }^{\top}$ and its closest phylogenetic neighbours

Values are based on at least two hybridizations.

\begin{tabular}{|lccc|}
\hline \multirow{2}{*}{ Strain } & \multicolumn{3}{c|}{$\begin{array}{c}\text { Hybridization (\%) with DNA } \\
\text { from: }\end{array}$} \\
\cline { 2 - 4 } & $\mathbf{1}$ & $\mathbf{2}$ & $\mathbf{3}$ \\
\hline 1. V. penaei sp. nov. CD276 & 100 & - & - \\
2. V. carniphilus CIP $108561^{\mathrm{T}}$ & $14 \pm 2$ & 100 & - \\
3. V. fluvialis LMG $9464^{\mathrm{T}}$ & $18 \pm 2$ & $23 \pm 0$ & 100 \\
\hline
\end{tabular}


Cells are Gram-stain-positive cocci, $0.5-1 \mu \mathrm{m}$ in diameter, and occur singly, in pairs or in short chains, elongated in the direction of the chain. Cells are non-motile and nonspore-forming, facultatively anaerobic and catalase- and oxidase-negative. Colonies are small (up to $1 \mathrm{~mm}$ in diameter), smooth and white when grown on $\mathrm{BHI}$ agar at $30{ }^{\circ} \mathrm{C}$. No haemolysis or pigment on Columbia agar supplemented with $5 \%$ defibrinated horse blood. Lactic acid is produced from glucose fermentation, but gas is not produced. Grows at $10{ }^{\circ} \mathrm{C}$ but not at $45{ }^{\circ} \mathrm{C}$. Does not grow with $6.5 \% \mathrm{NaCl}$. With API Rapid ID32S, acid is produced from maltose, melezitose, raffinose, D-ribose, sucrose, trehalose and $\alpha$-cyclodextrin, but not from L-arabinose, D-arabitol, lactose, D-mannitol, melibiose, D-sorbitol, Dtagatose, glycogen, methyl $\beta$-D-glucopyranoside or pullulan. Produces acid phosphatase, arginine dihydrolase, esterase (C4), esterase lipase (C8), glycyl-tryptophan arylamidase, naphthol-AS-BI-phosphohydrolase and pyroglutamic acid arylamidase, but not $\alpha$-chymotrypsin, $\alpha$ fucosidase, $\alpha$-galactosidase, $\beta$-galactosidase, $\alpha$-glucosidase, $\beta$-glucosidase, $\beta$-glucuronidase, $\alpha$-mannosidase, $\beta$-mannosidase, alkaline phosphatase, lipase (C14), alanyl-phenylalanyl-proline arylamidase, cystine arylamidase, leucine arylamidase, valine arylamidase, $N$-acetyl- $\beta$-glucosaminidase, trypsin or urease. Hippurate is not hydrolysed. Nitrate is not reduced. Acetoin is produced (VogesProskauer). The cell-wall peptidoglycan is type A4 $\alpha$ L-LysD-Asp and the predominant cellular fatty acids are cis-9 octadecenoic acid and hexadecanoic acid. The DNA G + C content of the type strain is $35.4 \mathrm{~mol} \%$.

The type strain is $\mathrm{CD} 276^{\mathrm{T}}\left(=\mathrm{LMG} 24833^{\mathrm{T}}=\mathrm{CIP} 109914^{\mathrm{T}}\right)$, isolated from the spoilage microbiota of cooked shrimp (Penaeus vannamei).

\section{Acknowledgements}

This study was supported by the Région Bretagne and the Région Pays de la Loire. We thank Florian Torselli for the molecular characterization. We are grateful to J. P. Euzéby for consultation regarding the species epithet. E. J. received a $\mathrm{PhD}$ grant awarded by Ifremer and ENITIAA.

\section{References}

Al-Ahmad, A., Pelz, K., Schirrmeister, J. F., Hellwig, E. \& Pukall, R. (2008). Characterization of the first oral Vagococcus isolate from a root-filled tooth with periradicular lesions. Curr Microbiol 57, 235 238.

Cole, J. R., Chai, B., Marsh, T. L., Farris, R. J., Wang, Q., Kulam, S. A., Chandra, S., McGarrell, D. M., Schmidt, T. M. \& other authors (2003). The Ribosomal Database Project (RDP-II): previewing a new autoaligner that allows regular updates and the new prokaryotic taxonomy. Nucleic Acids Res 31, 442-443.

Collins, M. D., Ash, C., Farrow, J. A. E., Wallbanks, S. \& Williams, A. M. (1989). $16 \mathrm{~S}$ ribosomal ribonucleic acid sequence analyses of lactococci and related taxa. Description of Vagococcus fluvialis gen. nov., sp. nov. J Appl Bacteriol 67, 453-460.

Ezaki, T., Hashimoto, Y. \& Yabuuchi, E. (1989). Fluorometric deoxyribonucleic acid-deoxyribonucleic acid hybridization in microdilution wells as an alternative to membrane filter hybridization in which radioisotopes are used to determine genetic relatedness among bacterial strains. Int J Syst Bacteriol 39, 224-229.

Felsenstein, J. (1985). Confidence limits on phylogenies: an approach using the bootstrap. Evolution 39, 783-791.

Fischer, W. \& Arneth-Seifert, D. (1998). D-Alanylcardiolipin, a major component of the unique lipid pattern of Vagococcus fluvialis. J Bacteriol 180, 2950-2957.

Gascuel, O. (1997). BIONJ: an improved version of the NJ algorithm based on a simple model of sequence data. Mol Biol Evol 14, 685-695.

Gevers, D., Huys, G. \& Swings, J. (2001). Applicability of rep-PCR fingerprinting for identification of Lactobacillus species. FEMS Microbiol Lett 205, 31-36.

Hall, T. A. (1999). BioEdit: a user-friendly biological sequence alignment editor and analysis program for Windows 95/98/NT. Nucleic Acids Symp Ser 41, 95-98.

Hashimoto, H., Noborisaka, R. \& Yanagawa, R. (1974). Distribution of motile streptococci in man, animals and natural environment. Nippon Saikingaku Zasshi 29, 387-393 (in Japanese).

Hoyles, L., Lawson, P. A., Foster, G., Falsen, E., Ohlén, M., Grainger, J. M. \& Collins, M. D. (2000). Vagococcus fessus sp. nov., isolated from a seal and a harbour porpoise. Int J Syst Evol Microbiol 50, 1151-1154.

Jaffrès, E., Sohier, D., Leroi, F., Pilet, M. F., Prévost, H., Joffraud, J. J. \& Dousset, X. (2009). Study of the bacterial ecosystem in tropical cooked and peeled shrimps using a polyphasic approach. Int J Food Microbiol 131, 20-29.

Kimura, M. (1980). A simple method for estimating evolutionary rates of base substitutions through comparative studies of nucleotide sequences. J Mol Evol 16, 111-120.

Lawson, P. A., Foster, G., Falsen, E., Ohlén, M. \& Collins, M. D. (1999). Vagococcus lutrae sp. nov., isolated from the common otter (Lutra lutra). Int J Syst Bacteriol 49, 1251-1254.

Lawson, P. A., Falsen, E., Cotta, M. A. \& Whitehead, T. R. (2007). Vagococcus elongatus sp. nov., isolated from a swine-manure storage pit. Int J Syst Evol Microbiol 57, 751-754.

Mesbah, M., Premachandran, U. \& Whitman, W. B. (1989). Precise measurement of the $\mathrm{G}+\mathrm{C}$ content of deoxyribonucleic acid by highperformance liquid chromatography. Int J Syst Bacteriol 39, 159-167.

Michel, C., Pelletier, C., Boussaha, M., Douet, D. G., Lautraite, A. \& Tailliez, P. (2007). Diversity of lactic acid bacteria associated with fish and the fish farm environment, established by amplified rRNA gene restriction analysis. Appl Environ Microbiol 73, 2947-2955.

Pot, B., Devriese, L. A., Hommez, J., Miry, C., Vandemeulebroecke, K., Kersters, K. \& Haesebrouck, F. (1994). Characterization and identification of Vagococcus fluvialis strains isolated from domestic animals. J Appl Bacteriol 77, 362-369.

Ruiz-Zarzuela, I., de Bias, I., Girones, O., Ghittino, C. \& Muazquiz, J. L. (2005). Isolation of Vagococcus salmoninarum in rainbow trout, Oncorhynchus mykiss (Walbaum), broodstocks: characterization of the pathogen. Vet Res Commun 29, 553-562.

Sasser, M. (1990). Identification of bacteria by gas chromatography of cellular fatty acids, MIDI Technical Note 101. Newark, DE: MIDI Inc.

Schleifer, K. H. (1985). Analysis of the chemical composition and primary structure of murein. Methods Microbiol 18, 123-156.

Schleifer, K. H. \& Kandler, O. (1972). Peptidoglycan types of bacterial cell walls and their taxonomic implications. Bacteriol Rev 36, 407-477.

Schmidtke, L. M. \& Carson, J. (1994). Characteristics of Vagococcus salmoninarum isolated from diseased salmonid fish. J Appl Bacteriol 77, 229-236.

Shewmaker, P. L., Steigerwalt, A. G., Morey, R. E., Carvalho, M. G. S., Elliott, J. A., Joyce, K., Barrett, T. J., Teixeira, L. M. \& Facklam, R. R. 
(2004). Vagococcus carniphilus sp. nov., isolated from ground beef. Int J Syst Evol Microbiol 54, 1505-1510.

Stackebrandt, E. \& Goebel, B. M. (1994). Taxonomic note: a place for DNA-DNA reassociation and $16 \mathrm{~S}$ rRNA sequence analysis in the present species definition in bacteriology. Int J Syst Bacteriol 44, 846849.

Stackebrandt, E., Frederiksen, W., Garrity, G. M., Grimont, P. A. D., Kämpfer, P., Maiden, M. C. J., Nesme, X., Rosselló-Mora, R., Swings, J. $\&$ other authors (2002). Report of the ad hoc committee for the reevaluation of the species definition in bacteriology. Int J Syst Evol Microbiol 52, 1043-1047.

Tamura, K., Dudley, J., Nei, M. \& Kumar, S. (2007). MEGA4: molecular evolutionary genetics analysis (MEGA) software version 4.0. Mol Biol Evol 24, 1596-1599.

Teixeira, L. M., Carvalho, M. G. S., Merquior, V. L. C., Steigerwalt, A. G., Brenner, D. J. \& Facklam, R. R. (1997). Phenotypic and genotypic characterization of Vagococcus fluvialis, including strains isolated from human sources. J Clin Microbiol 35, 2778-2781.

Valcheva, R., Ferchichi, M. F., Korakli, M., Ivanova, I., Gänzle, M. G., Vogel, R. F., Prévost, H., Onno, B. \& Dousset, X. (2006). Lactobacillus nantensis sp. nov., isolated from French wheat sourdough. Int J Syst Evol Microbiol 56, 587-591.

Wallbanks, S., Martinez-Murcia, A. J., Fryer, J. L., Phillips, B. A. \& Collins, M. D. (1990). 16S rRNA sequence determination for members of the genus Carnobacterium and related lactic acid bacteria and description of Vagococcus salmoninarum sp. nov. Int J Syst Bacteriol 40, 224-230.

Wayne, L. G., Brenner, D. J., Colwell, R. R., Grimont, P. A. D., Kandler, O., Krichevsky, M. I., Moore, L. H., Moore, W. E. C., Murray, R. G. E. \& other authors (1987). International Committee on Systematic Bacteriology. Report of the ad hoc committee on reconciliation of approaches to bacterial systematics. Int J Syst Bacteriol 37, 463-464. 